\title{
Military Hygiene on Active Service
}

\author{
Major T. H. J. C. Goodwin D.S.O., R.A.M.C.
}

To cite this article: Major T. H. J. C. Goodwin D.S.O., R.A.M.C. (1906) Military Hygiene on Active Service, Royal United Services Institution. Journal, 50:340, 737-765, DOI: $\underline{10.1080 / 03071840609436386}$

To link to this article: http://dx.doi.org/10.1080/03071840609436386

曲 Published online: 11 Sep 2009.

Submit your article to this journal

LII Article views: 3

Q View related articles $\sqsubset$ 


\title{
MILITARY HYGIENE ON ACTIVE SERVICE:
}

\author{
By Major T. II.J.C. GOODWIN, D.S.O., R.A.M.C.
}

\author{
Thursday, 18th January; 1906, at 3 p.m. \\ Surgeon-General A. KEoGH, C.B., M.D. (Director-General, \\ Army Medical Service), in the Chair.
}

WHILE fully appreciating the honour of reading a paper at this Institution, I confess that it is with feelings of hesitation that I attempt to deal effectively with a subject of such extent and importance.

The range covered by this branch of science is so great that I fear it is quite impossible for me to do more than briefly describe the origin and causation of those diseases which affect our armies on active scrvice, and to then review shortly those measures which will, I hope, prove effectual in the future in preventing those epidemics of disease which have been such a prominent and lamentable feature of our campaigns in the past.

As to the importance of this subject:- Is this thoroughly realised? It certainly has not been so in the past, and the health of our Army, and, consequently, its fighting efficiency, has suffered terribly in consequence.

There can be no possible doubt but that the importance of this subject should be recognised, not only by medical officers like myself, but also by all branches of the Army, for there is abundant evidence to show that the future success of our Army in the field must, and will, to an enormous extent, 'depend upon the efficiency with which measures for the prevention of disease are carried out.

There is, $I$ think, a general idea that the losses on active service are due to a certain number of officers and men being killed and wounded.

This impression is, to a very great extent, fallacious.

On recent campaigns, the proportion of our losses from wounds, as compared with our losses from preventible disease-I lay stress on the word "preventible"-has been very small indeed.

Take as an example, one of the most fatal diseases on active service: enteric fever.

During the recent war in South Africa there were over 41,000 cases of enteric fever.

Quite apart from the terrible loss of health and life which this disease involved, the cost to the State of invaliding and replacing these men amounted, I believe, to nearly four millions sterling, and this is taking into consideration the case of one disease alone.

As a contrast to this I may mention that the casualties sustained by General Oku's. Army in Manchuria, from 6th May to 19th December, 1904, were 26,207 killed and wounded, while, during the same period, there were only 193 cases of enteric fever.

vor. $\mathbf{L}$. 
This is, as the British Medical Journal (4th February, 1905), observes, "a very remarkable record, affording a striking proof of the efficiency of the precautions recommended by the Japanese Medical Department, and accepted by the commanders in the field for the protection of the men."

During the whole of the recent war, Japan lost 57,000 from wounds, and 15,000 from sickness, the deaths from sickness being icss than one-fourth the total loss, a proportion without parallel in the records of war.

In the South African War there were, in round numbers, 400,000 admissions to hospital for disease, and 18,000 for wounds, so that, for every man admitted to hospital wounded, there were 22 admissions for sickness.

Laying aside all sentimental considerations as to loss of health and life, and looking at the matter from a purely practical standpoint-I presume that the main object in warfare is to win battles, and to win them as speedily as possible. Other things being equal, I presume that the side, which has the greatest number of effectivo fighting men, will win the day.

When we think of the numbers I have just quoted, and realise that the fighting value of 400,000 men was lost to the British Army at one time or other during the recent war, we may appreciate the effect which disease has on the probable outcome of a struggle between two nations.

I imagine that nothing can be more disheartening for an officer commanding any unit in the field than to sce his men falling out in increasing numbers every day, and to see men, who should be in the fighting line, drifting away to the field hospitals, where they are lost to him and to the Army as far as their fighting value is concerned.

When such an officer realises that practically all this loss from sickness might have been prevented, the bitter fact that the force under his command has been clecimated, and rendered practically useless from disease, will be rendered more bitter still.

Now with whom does the responsibilty for the prevention of disease lie?

I think that there is a general idea that it lies, solely and entirely, with the medical officers.

While fully recognising that it is the duty of medical officers to make recommendations, and to do all in their power to ensuro that every possible measure for the prevention of disease is carried out, I would point out that, unless regimental and staff officers are in sympathy with such recommendations, and unless both they, and also the non-commissioned officers and men under them, understand the reason of the preventive measures, recognise their importance, and endeavour to efficiently and intelligently carry them out, it is extremely improbable that a successful result will be obtained.

When discussing this matter with combatant officers, $I$ have often been told: "Well, after all, my duty is to fight, and to teach my mien how to do so; questions regarding their health, and the prevention of diseasa, are your business."

I think that this is entirely a wrong standpoint from which to look at the matter; fighting is most certainly the primary duty of the combatant officer, but I maintain that it is also a most important part of his duty to maintain the physical efficiency, and, concurrently, 
tine fighting capability, of his men, and he cannot possibly do this unless he has a clear knowledge of the principles of disease causation and prevention, and applies that knowledge to the conservancy of his camp, the supply of drinking water, and many other details. Ho cannot always have a medical officer to fall back upon for advice; occasions are constantly arising when he is on detached duty, probably with a small body of men, and he will then have to act on his own knowledge and judgment, and on him.will depend entirely the question as to whether, in a few weeks' time, he will still have under him an efficient body of fighting men, or whether these will have dwindled to a fraction of their original strength, many of them having been admitted to hospital with enteric fever or dysentery, while of the remainder the number of ineffectives is daily increasing.

We cannot have a clear conception as to what measures will be effectual in the prevention of disease, unless we have a sound and definite knowledge as to the manner in which that disease is caused.

Of late years our knowledge as to the origin and causation of cisease has become immensely advanced, many of the old vague ideas have been swept away, and accurate scientific facts have taken their place.

I presume that everyone hero has heard of baeteria. These organisms are the real and actual factors in the causation of disease, and it has been definitely and clearly proved by scientists, that certain specific bacteria cause certain specific diseases, and that these diseases can ariso from no other cause whatever than by the entry, into the liuman body, of the bacteria which cause them.

Time will not permit me to describe any of the numerous experiments by which this fact has been proved, and I must consequently ask you to accept my statements on trust, and to believe me when $I$ assure you that there is abundant indisputable evidence to prove them.

Any ideas, as to the possibility of disease arising of itself, should be dismissed, once and for ever, from our minds. Tho days have now passed by when men, even well-educated men, spoke in a vague manner, and possibly with a doubting smile, of the "germ theory of disease." The causation of disease by germs, or, in other words, by bacteria, is no vague theory, it is a definite and well proved fact, admitting of no doubt or question whatever.

Anyone who takes an interest in this matter, and cares to look further into it, cannot do better than read the "Life of Pasteur," a book of the greatest interest, not only to men of my profession, but almost equally so to anyone taking an interest in the matter.

I shall not enter into a detailed description of bacteria, but I should like to mention a few of their more important characteristics.

Firstly, as to their powers of multiplication. These organisms multiply with immense rapidity, the process taking place by fission.

Under favourable conditions of warmth and moisture, such, for instance, as the bacterium finds on entering the human body, it will, within one hour, divide into two parts, at the end of a second lour each of these parts will have again divided, and the process of subdivision continues, until, at the end of twenty-four hours, calculation shows that the original single bacterium will havo multiplied to a number exceeding sixteen millions.

Now we will suppose that a single bacillus, or rod-shaped organism, of enteric fever or dysentery has entered the body of a human being, it 
is easy to undertand how, at the end of a few days, his whole system will be teeming witl countless millions of bacill, which are hourly being given off in his excrota, to pollute the soil, and hence, in all probability, to enter food or water, and so gain access to, and infect with the disease, fresh persons.

It is in this manner that an epidemic of disease commences, and, unless successfully taken in hand, it decimates a body of troop with fearful rapidity.

As to the conditions of bacterial existence, they like warmth and moisture, consequently the interior of the human body is extremely favourable for their growth and multiplication.

They are very resistent to cold, and may be frozen for long periods without being killed, but they are quickly destroyed by excessive heat, as by being boiled, or by the action of certain chemicals, known as antiseptics.

The mode of entry of bacteria into the human body is usually by one of three channels:-

1. Inspiration; i.e., the bacteria are inspired with the air into the lungs, where they lodge, and set up the disease, as in pneumonia.

2. Ingestion; they are swallowed, and conveyed to the intestinal tract, as in enteric fever, dysentery, and cholera. This is by far the most important channel of entry of those diseases which affect an Army in the field.

3. Penetration of the skin, as in plague, etc.

A few words as to the manner in which the bacteria themselves cause the disease.

As a general rule, toxines, or poisons, are manufactured by the hacteria during the processes of growth and multiplication, these toxines act on the tissues of the body, and cause the various symptoms of the disease, headache, fever, etc.

It does not invariably follow that every person, whose system has been invaded by the bacteria, contracts the disease immediately. In certain cases they may remain dormant in the body until the system becomes lowered, as by fatigue, hunger, diarrhcea, etc., and they may then wake into activity, and, overcoming the natural resisting power of the body, set up the disease.

So much for the causation of the disease; wo will now consider its prevention.

In speaking of the prevention of disease $I$ am afraid that it is impossible for me to avoid going over a certain amount of ground which has already been trodden by others.

I must apologise if I speak of facts and rules which are already well known to all of you, but it is difficult for me to altogether exclude many, rules and principles, which are possibly almost universally known and accepted.

In dealing with disease prevention on active service I shall speak of the two following maladies conjointly, viz.:-Enteric fever and dysentery.

These two diseases are together responsible for by far the greater proportion of our losses on active service, and it is convenient to discuss them together, as the bacteria causing them enter our bodies in the same manner, viz., by being swallowed, and, consequently, proventive measures are the same for both of them. 
I. think we may consider the means of prevention under two

1. Measures which prevent the entry of the bacteria into our bodies.

2. Measures which maintain the health, and, consequently the resistent power of the individual.

To deal with the first group:-

The main channels through which the bacteria gain access to our bodies are:-

1. Water.

2. Food.

3. Flies.

4. Dust.

5. Soil pollution.

We will now consider these channels separately :-

1. Water.

All existing water supplies must be protected from contamination.

I do not propose to enter into all the rules regarding the subject of water protection, they have been laid down many times, and are to be found in every book on military hygiene.

I should like, however, to point out that all these measures must be carried out zealously and intelligently; if performed in a perfunctory and half-hearted manner the result will be valueless. For instance, it is not sufficient to publish an order to the effect that a certain supply of water is unfit for drinking purposes-such steps should be taken as will render the use of the water an impossibility.

If the water were originally pure and uncontaminated, the measures laid down would, if carefully carried out, effectually prevent the introduction of disease from this source, but, unfortunately, on $\theta$ is obliged to regard most water supplies, certainly those in India, as already, to a greater or less extent, contaminated.

Anyone whe has been in India, and has noticed the ordinary habits of the native, will readily understand that this is the case. This being so, while every effort must be made to prevent further contamination, the question of the purification of the water must be considered.

The principal means by which water may be purified are:-

a. Heat (boiling).

b. Filtration.

c. Chemicals.

We will now consider these in rotation:-

a: Boiling.

This is an. excellent measure, for, as.I have already mentioned, the bacteria of disease are quickly killed by boiling, and water, if boiled for one minute or longer, is effectually sterilised, i.e., any bacteria which it contains are destroyed, and it may be subsequently drunk with impunity. There are, however, various difficulties to be overcome. One of these is the question of fuel, which it may not be possible to obtain in sufficient quantity, or to transport; a second difficulty is the necessity for cooling the water before it can be drunk; and $a$ third is due to the fact that, if the water is boiled for more than a few minutes, it loses its dissolved gases and becomes unpalatable. 
As to the means by which these difficulties may be overcome:-

The first, as to fuel, may, to a considerable extent, be surmounted by using a stove on the primus principle, which consumes oil; by means of such a stove about 20 to 25 gallons of water can be brought to the boiling point with an expenditure of about eight ounces of oil.

Unfortunately, the primus stove is extremely liable to get out of order, it requires to be carefully screened from the wind, and must also be absolutely protected from dust and grit.

Captain Scott, in his very interesting account of the voyage of the "Discovery," remarks especially on this point, and lays stress on the fact that this stove is only efficient if worked by a man who thoroughly understands it, otherwise it speedily gets out of order and consequently becomes useless.

The second difficulty, as to cooling the water, may be overcome in various ways; one method is that employed in the Forbes-Waterhouse steriliser, which is used in the United States Army. In this apparatus, by means of a heat exchange mechanism, the water, after having been boiled, parts with a considerable amount of its heat to the incoming water which has not yet been heated.

It is claimed for this steriliser that, in one pattern, the outgoing sterile water is only $4 \frac{1}{2}$ degrees higher in temperaturo than it was on entering the apparatus.

This steriliser is spoken of as having worked well in the United States Army, but I believe that it is still more or less on its trial, and I think that the perfect apparatus remains to be found. I believe that, in the more recent pattern, in which weight has been, as far as possible, minimised, the water is not cooled to nearly the same extent as in the earlier, and heavier, design.

The third difficulty, as to taste, may be overcome- by boiling the water for such a short period that, although the bacteria are killed, yet the greater proportion of the dissolved gases remain in the water, which is, consequently, palatable.

The Forbes-Waterlouse steriliser is a delicato apparatus, and, unless transported and worked by men who thoroughly understand its mechanism, it is very liable to get out of order and become useless; it is evident, therefore, that it should be supervised and managed by trained men, and not handed over to anyone except a person who is thoroughly conversant with it.

The water must be clarified from mud and coarser particles before being passed through the steriliser, for not only will water containing sediment or mud be unpleasant to drink, but; owing to the mechanical irritation caused br the particles which it contains, it will be extremely likely to produce diarrhœa.

The water of many of the rivers in Ladakh and Kashmir and on the North-WVest Frontier contains large quantities of mica in suspension, and, unless this is removed before the water is drunk, diarrhœa of an extremely severe nature will almost certainly result.

Water-boiling on a large scale may be carried out in standing camps.

In Ladysmith sterilisation was effected by Colonel Sim's apparatus, in which the water was first boiled, the sediment precipitated by the addition of alum, and the water was then cooled in a separate cylinder before issuc. 
This apparatus delivered about 3,000 gallons per day, and $I$ believe that the results from its use were eminently satisfactory.

We now pass to the second method, that of filtration. There are several fairly satisfactory forms of filter at present in use, of which the Berkefeld is perhaps the best known.

The following points must be observed with regard to all of them:-

1. The water must be clarified from coarser particles, sand, mud, etc., before being passed through the filter, otherwise the apparàtus will speedily become choked and useless.

This primary filtration is usually effected by means of a barrel or basket, containing charcoal or sand and gravel, or by means of bags of canvas or blanket, or some such simple method.

2. The filter must be regularly, thoroughly, and skilfully cleansed, otherwise it will speedily become worse than useless. The Berkefeld filter should be' thoroughly, cleansed at least every third day.

3. The filter must be looked after, and worked, by skilled and careful men; even in their hands the apparatus is liable to get out of order, owing to "the rough usage of active service, and this is much more likely to happen if the filter is handed over to men who do not thoroughly understand it, and realise the care necessary to ensure its efficiency.

It is manifest that filtration is purely a mechanical process, and cannot have any eliminating effect. on substances which may be in solution, so that it is evident that chemical poisons, dissolved in the water, will not be excluded by filtration.

Consequently, no matter by what process sterilisation is carried out, the source of the water, well, spring, or stream, must be kept as clean, and free from decaying animal and vegetablo matter, as possible.

There is a new pattern water cart, which is at present on trial, in which the water passes through a filter in the interior of the cart, and is consequently purified before being drawn off. I believe that this cart promises well, but I cannot speak of it from personal experience.

A minor, but an extremely important point, and one which can be seen to by the company officers only, is the water in the men's bottles.

It should be absolutely ensured that these water bottles are only filled with such water as has been previously sterilised by boiling, or other method.

- The men's bottles should be thoroughly cleansed with boiling water at regular periods.

Men should be instructed and trained to husband the supply in their bottles. This is entirely a matter of habit and training; if a man commences to drink within the first fow miles of a march, ho will certainly continue to do so at frequent intervals, and will very soon finish the supply in his bottle, and will then, if he can, drink. from any water which he may happen to come acrosss, 
This is a point on which the discipline in the Japanese Army is extremely strict, and $\mathbf{I}$ believe that it is most unusual for tho Japanese soldier to drink from any unauthorised water supply.

Sir Ian Hamilton, in his recently published book, draws attention to this fact, and states that the Japanese soldier neglects no rule of sanitation, and is most scrupulously particular in carrying out every measure which. is conducive to the maintenance of his health, and consequently, of his efficiency as a fighting man.

In reviewing these two different methods of water sterilisation it is impossible to say definitely that either method is the better.

In somo instances boiling can be effectually carried out, and will prove satisfactory, while, under different circumstances, filtration will prove to be the most efficient means of sterilisation. As a general rule I think that, while at the base and on the lines of communication, sterilisation can best be carried out by boiling; at the front the water can most readily be purified by filtration.

As regards the comparative utility of the different appliances for sterilisation I think that the perfect apparatus is still to be found, but at the same time, I think that several of those in use at present. will prove quite efficient, if worked by men who thoroughly understand their mechanism.

To my mind this a most important point, for it is impossible that a good result can be expected if an apparatus, such, for instance, as a Forbes-Waterhouse steriliser, or a complicated filter, be handed over to men who have an insufficient knowledge of the mechanism of such articles, and possibly the crudest ideas as to the methods of sanitary science.

As regards the third method of water purification, namely, that by chemicals, I shall say but little. It is manifest that there are many difficulties in the application of such methods on active service.

At the same time I think that there is scope for the employment of such a method as Vaillard's in sterilising the water for omall. detached bodics of men, such as picquets and scouting parties.

In this method the water is purified by the action of free iodine, which is subsequently neutralised by the addition of hyposulphite of soda.

The materials are very portable, and the process of sterilisation is extremely simple, and, $I$ believe, efficacious.

2. Food.

Turning now to the question of food :-

A considerable portion of food on active service is issued in tins.

These tins should be very carefully inspected on issue to the men, and any which are bulged or indented, or which emit a hollow sound when struck, showing that putrefactive gases are forming in the interior, should be rejected.

Tins may be perfectly sound when inspected, and issued in bulk, at the base, but may become injured, and their contents poisonous, before issue to the men some days or weeks later.

Tins of food should be carefully packed in straw, etc, in order to avoid injury, and should, if possible, be stored in a cool place.

The quality of the cooking, and variety in the food, are matters which necessitate attention. 
It should be borne in mind that dyspepsia and diarrhœa, which may easily be induced by bad cooking, or by a monotonous diet, and which, of themselves, are comparatively minor evils, predispose to the much graver diseases of enteric fever and dysentery.

I now come to the third channel of infection:-

\section{Flies.}

These insects play an extremely important part in the conveyance of the bacteria of disease.

This had been repeatedly proved; for instance, flies have been allowed to settle on the discharges from patients suffering from enteric fever, and the insects have then been permitted to walk on plates of gelatine, the result being that colonies of enteric bacilli have developed in their tracks.

There is no proof that the enteric bacilli pass through the digestive tract of the fly, but there is clear evidence that they adhere to the legs, wings, and bodies of these insects. Another experiment is that of placing two jars of sterilised milk side by side, leaving the mouth of one open, and so exposed to the incursions of flies, and covering the other with coarse muslin.

At the end of twenty-four hours the milk in the exposed jar is found to be swarming with bacteria, the milk in the protected jar remaining sterile.

There has been abundant evidence of late years to prove the large part which flies play in the spread of disease.

Dr. Nuttall, of Cambridge University, states that he considersthe evidence as to the rôle of flies in the diffusion of cholera as "absolutely convincing:"

The commission appointed to investigate the cause of the epidemic of enteric fever in the Volunteer camps in the United States, during the Spanish-American War of 1898, stated that the spread of the fever was, in their opinion, effected by flies.

During this campaign the epidemic of enteric fover gradually decreased with the approach of the cold weather, when the flies became disabled, and unable to carry the germis of infection.

The same fact has been noted for some years in South Africa.

When the prevailing wind is from one direction, a fly-borne infection will extend In the same direction as the wind, as the insects, on rising in the air, are carried along by the breeze.

As regards the life history of the common fly. The female insect lays eggs, to the number of about one hundred and twenty, in decaying organic matter, especially in the crevices of horse dung; the larva, or maggot, is hatched out from the egg in twenty-four hours' time; after a period of from five to seven days this larva becomes a pupa or chrysalis, and from this pupa, after a further period of five to seven days, the fully-developed fly emerges.

Consequently, the mature fly is developed from the egg in about a fortnight.

The adult insect feeds on any dead animal matter, and, if permitted, will divide its attentions impartially between the latrines and the men's food supplies.

As to the measures which should bo adopted in order to chock the spread of the disease by flies-these practically resolve themselves into the protection of food from their incursions, the destruction of 
their breeding places by the removal of all horse litter and refuse, and the careful supervision of the latrines, for it is-in the latrines that the insects come into contact with the bacteria which cause disease.

As regards the destruction of refuse, Major Caldwell, in his book on disease prevention, describes an improvised destructor which I should think would answer excellently in the absence of special apparatus.

It simply consists of two short trenches intersecting each other at right angles, with a chimney at the point of intersection. $A$ fire is lighted at the base of the chimney, and the rubbish is thrown down from the top; by this means the refuse is more completely destroyed than it is when burned in the open.

Latrines in standing camps should, when possible, be thoroughly and regularly disinfected by quick-lime and water, or other means, and dry earth with scoops must be provided in every latrine, temporary or permanent, and this earth must be freely used by the men.

4. Dust.

With the question of dust I shall deal briefly, it is an undoubted factor in the dissemination of disease.

Experiments by Firth and Forrocks prove that enteric bacilli can live in dust or dry earth for over three weeks, so that one can readily understand how, if latrines are left uncovered, a spell of dry weather, followed by a storm, will spread the germs of disease all over the camp.

\section{Soil Pollution.}

I now pass on to the question of soil nollution; I have left it to the last, but it is, probably, the most important factor of all in the spread of disease.

New camps are as a rulo, healthy; after they have been occupied by a succession of troops they becomo very much the reverse.

Camps are often left in an extremely dirty condition when troops vacate them, this condition being especially noticeable in the vicinity of latrines; when the next troops arrive on such a camping ground they are bound to suffer in consequence.

The ideal method would be for no camping ground to be occupied by successive bodies of troops, each unit, as it arrived, being located on a fresh site, but this is manifestly impracticablo in many instances, and consequently every care must be taken to prevent soil pollution.

Before I go further I should like to bring two facts, regarding enteric fever, to your notice.

The first is that the bacilli of this diseaso are, in many cases, voided in a person's excreta for some time before he shows any manifestation of the disease itself, consequently, a man may appear to be quite healthy while his excreta are swarming with the bacilli.

The second point is that the enteric bacilli are voided in largo numbers in the urine.

From these two facts wo can understand how important it is that men, whether healthy or sick, should, under no circumstances, be permitted to go elsewhere than to the latrines or urinals for the purposes of nature.

Whenever troops are halted, even for half a day, latrine trenches must be dug, and the men must, on no account, be permitted to uso any other place.

This is a point which has been very frequently neglected in the 
past, and .men, when halted for short periods, have not been prevented from strolling, for the purposes of nature, into the jungle or rough ground in the vicinity of the camp. This custom is fraught with disastrous consequences, for the result is that the ground in, and around, the camp, becomes contaminated, and any troops which may subsequently be located there will inevitably suffer.

The question of the supervision and care of latrines and urinals is an extremely important one; as soil pollution is directly dependant on the condition in which these are kept.

The supervision of latrines is an unpleasant duty, and is, consequently, extremely likely to be "shelved," everyone relegating the duty to someone else, the result in the end being that the supervision of the latrines is neglected, their condition speedily becomes the reverse of sanitary, and an outbreak of enteric fever or dysentery follows.

If sanitary precautions regarding latrines, urinals, and the disposal of refuse, are scrupulously carried out, the worst evil of all, soil pollution, will be, to a very great extent, prevented, and, the greater the degree of this prevention, the better will the health of the troops be, and the less the incidence of enteric fever and dysentery.

I have already stated that I consider this question of the disposal of excreta, and consequent presence or absence of soil pollution, to bo the most important factor of all in the prevention of disease.

Bearing in mind what. I have already stated with regard to disease causation, we can see how all these other channels of cntry, water, food, flies; etc., depend upon the presence or absence of soil pollution.

The fons et origo mali, the bacillus, is present in the excreta of the affected person, if this bacillus is permitted to gain access to the water supply, or to be carried-by flies, dust, etc., to food, an outbreak of disease will follow, and, consequently, all these channels depend, in the first instance, on the disposal of excreta.

I think that $I$ have now sooken at sufficient length regarding these discases, and shall pass on to briefly consider the question of malaria.

I have decided to say a few words regarding this group of diseases on account of the great extent to which our Armies on the frontier of India are affected by it.

Although malaria does not cause the severe epidemics of disease which arise from enteric and dysentery, still, it incapacitates a very large number of men, and renders them useless to the fighting force for the time being.

Malaria was formerly ascribed to various vague causes, " miasma," chill, etc.

It was discovered, many years ago, that the causative factor of the disease was a small animal organism, which, having obtained access to the blood of human beings, fed upon, and destroyed, the red blood corpuscles.

The means by which this parasite entered our bodies remained for many jears unknown, and our present knowledge on the subject is very largely due to the researches of Major Ross, in the Indian Medical Service.

Ross discovered that the organism was transmitted to man and animals through the agency of a particular species of mosquito, called the Anopheles. 
The mosquito most commonly met with, in India and other countries, belongs to the genus Culex, and the insects belonging to this class, although they suck blood freely, do not convey the organism of malaria.

The distinctive naked-eye appearances of the Anopheles and Culex mosquitoes are mainly as follows:-

In the Anopheles, the thorax, or anterior portion of the body, presents three longitudinal stripes, its wings are spotted, the head, thorax, and abdomen are in a more or less straight line. When the insect is in a resting position, its attitude approaches the vertical, the body of the insect forming an angle with the surface on which it rests.

The Anopheles mosquito does not migrate far from its breeding ground, and it only feeds between sunset and sunrise.

In the Culex, the head and thorax together form an angle with the abdomen, so that the insect presents a somewhat "hump-backed" appearance, and its resting attitude approaches the horizontal, so that the body of the insect lies more or less parallel with the surface on which it rests.

This variety feeds throughout the day and night.

There are many other scientific distinctions between the two species, into which $I$ shall not enter.

The female mosquito lays her eggs in water, these eggs are hatched, on the second or third day, into larve; these are little wriggling largelieaded creatures, which we may see by the hundred in any pool of water in India. emerge.

The larvæ become pupæ, and from these pupæ the perfect insects

The process of development, from egg to the perfect insect, occupies about a month.

- Each female mosquito commences to lay eggs when about a week old, she lays several hundreds at a time, and continues to lay them in batches throughout the summer, so that one pair of mosquitoes produces many millions of progeny in a season.

The female Anopheles usually selects, as her breeding place, small collections of water in the vicinity of houses, irrigation channels in gardens, stagnant pools, etc.

The problem as to the means of destruction of these mosquitoes, and their breeding places, by drainage, and other means, has attracted much attention of recent years, and excellent results have been attained in some places.

On active service the following are the main points to be observed with regard to the prevention of malaria:-

1. See that all measures recommended as to the use of mosquito curtains, etc., are, whenever possible, carried out.

2. Avoid camping in the immediate vicinity. of water, particularly of stagnant pools or sluggish streams.

3. The vicinity of villages, the inhabitants of which are known to be fever-stricken, should be carefully avoided.

4. Adopt every measure for maintaining the general health of the men.

I now pass to the second group of measures for the prevention of disease, namely, those which serve to maintain the health, and, consequently, to increase the power of the individual for resisting the inroads of bacteria. 
I shall deal very cursorily with matters under this heading. Most of the measures for maintaining the general health are known to all regimental officers, who, in my experience, spare no efforts to ensuro that the men under them are well looked after in the way of clothing, food, etc.

- I shall just mention a few of the more important necessities.

Firstly, overcrowding must be, as far as possible, avoided; of course, the exigencies of active service are such that it is sometimes impossible to avoid massing a large number of men on a limited area of ground, but, whenever means admit, ample space should be provided, for there is no doubt that overcrowding is invariably followed by disease.

As to clothing, it should, whenever possible, be ensured that, after a long march, the men change into a dry shirt before lying down.

There is one point with regard to clothing which, in my opinion, is of the greatest importance, and that is the cholera belt.

I am quite certain, and I think that the majority of medical officers will agree with me, that a warm dry flannel belt around the abdomen is of the utmost service in helping to ward off chills, and consequent attacks of diarrhoea and other maladies, which, as I have already pointed out, predispose to more serious diseases.

Such a belt should invariably be worn at night time.

Men should bo instructed to report sick without delay if they have any symptoms of diarrhoea. If this rule were invariably carried out, many attacks might be cut short and prevented from becoming serious.

As to marching, men should be marched in close formation as little as possible.

The reasons for this are that, when in close formation, men are breathing more or less foul air, which is not only thick with dust, but is also to a great extent, laden with the products of respiration.

As there is less circulation of air the men get much more heated and prone to suffer from heat stroke.

Vith regard to halts-prolonged halts are objectionable, frequent short halts are much more advisable in every way.

If marched for. several miles, and then given a long rest, the muscles become stiff, and, when the march is resumed, the men are feeling far more languid and fatigued than if halted for shorter periods at more frequent intervals.

I think a good average to allow is about fifteen minutes at the end of the first two miles, and after that to halt for ten minutes every hour.

Food should only bo sparingly partaken of while on the march, the principal meal being eaten after arrival in camp.

The advisability, or the reverse, of the use of alcohol on active service has frequently been debated.

The consensus of opinion is undoubtedly against the use of alcohol unless under exceptional circumstances.

Useful as it is at times, as, for instance, after a long and tiring march, when the men are exhausted, it is probably, if given as a routine measure, productive of nothing but harm.

There is no doubt that men improve considerably in physical condition during periods of enforced abstinence.

The practice of serving out tots of rum, as a routine measure, on cold nights, is certainly harmful, the liquor induces a feeling of 
warmth at the time, as the blood vessels on the surface of the body become dilated and flushed, but this simply means that so much reserve heat is given off from the body, which is consequently left in a less fit condition to combat tr : cold.

And now I think that I have given a very brief outline of somo of those measures for disease prevention which should be carried out on every campaign.

Our experience in the past has been, as regards epidemics of preventible disease, an unhappy one.

What can be done in order to effect an improved condition of affairs in the future?

Perhaps this question is one which hardly comes within my province. The control and regulation of matters concerning the broader lines of Army sanitation and the subjects bearing on it, lie 'in abler hands than mine; but I may perhaps be permitted to give my opinions, and, even if they are not accepted or agreed with, they will probably elicit other views, and lead to a discussion which may be of service to others, and most certainly will be so to myself.

Firstly, I do not think that epidemics of disease on active service can be entirely prevented by the adoption of any one sanitary measure, such, for instance, as water-boiling.

In saying this, I hope that I may not be misunderstood; nothing is further from my thoughts than a desire to belittle in any way the necessity for the purification of drinking water by boiling or any other efficient method. As I have already stated, this measure is of extreme importance; but I do not think that it will of itself prove a panacea in the prevention of disease.

I think that we must, while neglecting no details, approach the problem on broader lines than this.

To my mind there are two principal measures which are needed with regard to the sanitation of our Army on active service, and these two measures, if organised and perfected, would, I think, entirely remedy the great evil whinh bas existed in the past.

The first measure is sanitary organisation. I think that a sanitary corps of officers and men should be formed, who would be specially trained in all the methods of sanitation and disease-prevention. On such a corps would devolve the duty of seeing that the Army was kept up to date in all sanitary requirements.

With the officers would rest, subject of course to the military exigencies of the moment, decisions as to the selection of sites for camps, installation of water supplies, and many other. important matters.

Sterilisers, filters, destructors, and other sanitary appliances should be under the supervision of the members of this corps, and it could thus be ensured that these appliances were worked by skilled men only, and such as were conversant with their mechanism and requirements.

$I$ think that the formation and efficient training of such a body would be of the utmost service in the prevention of epidemics and in lessening the incidence of discase on a campaign.

Now, would the formation of such a corps fulfil all requirements, and succeed in attaining the desired end?

No, I do not think that it would; and $\dot{I}$ now come to the second point, and that is, the necessity for the further education in sanitary principles of regimental officers and men. 
I'his is, to my mind, an equally pressing necessity.

I do not of course mean for a moment that it is necessary for regimental officers and men to become experts in sanitation, but I do mean that they should understand the principles of the subject: the manner.in which disease arises, and the means by which it can be prevented.

Sanitary reform cannot, in my opinion, be effected entirely by the formation of a sanitary corps, or by improved methods of water purification. It must also be carried out by the officers and men of every unit.

I am convinced, in my own mind, that regimental officers and men are as a rule extremely deficient in knowledge of the causation and prevention of disease on active service.

Here again I hope I may not be misunderstood. I do not wish in any way to try to impute blame to, or to accuse of culpable ignorance, the officers or men of any branch of our Army; lack of knowledge on this subject is not their fault; it is the inevitable consequence of the conditions under which our Army exists in this country.

Under peace conditions, regiments live under the most favourable circumstances as far as sanitation is concerned.

All sanitary measures are carried out for them; when in barracks, sanitation proceeds automatically, and probably hardly comes under their notice at all, and even when in camp a supply of pure water is probably laid on, and rightly so, and all refuse and excreta are removed daily by contractors.

Let us consider what happens when these same regiments suddenly proceed on active service. Conditions then assume a vastly different aspect; everything has to be arranged, and all details carried out, by the officers and men themselves, and, inefficiently equipped with knowledge as they are, the performance of sanitary necessities. in the units will be inefficiently carried out, with the inevitable resplt that outbreaks of disease will follow, and the physical efficiency of the unit, and consequently its fighting capacity, will steadily and rapidly deteriorate.

The formation of a sanitary corps will not remedy this; sanitation should be, and in many instances must be, carried out by the units themselves.

Even if the rules published for guidance are followed out in a rule of thumb manner, the methods will probably break down from the neglect, through lack of knowledge, of some simple measure; which, though sufficiently evident to anyoue who has a certain amount of education in the causation and prevention of diseases, might not suggest itself to one who was lacking in knowledge on the subject.

For instance, a junior officer or even a non-commissioned officer finds himself in command of a detached body of men in a place where he has no one to fall back upon for advice. In such a case he should most certainly be fully competent to himself arrange for the protection and supply of water, the care of food, and abovo all, for the avoidance of soil pollution.

If lacking in knowledge on these points it will most probably happen that details are neglected, and that this small body of men will not only themselves become ineffective through sickness, but that they will also be the means of causing an outbreak of disease in the troops which subsequently occupy their camping ground. 
I think that it is fully as important that officers and men should be competent to carry out such simple measures for disease prevention as it is that they should be able to take cover when necessary during an engagement and to shoot straight.

As I said before, many more men are rendered ineffective by disease than by the bullets of the enemy.

If all regimental officers and men had a definite knowledge as to how disease was caused, they would I think apply the rules for its prevention in a common-sense and practical manner.

If one soldier realised that the fact of his comrade using other places than the latrines for the purposes of nature would most probably lead to the contraction of enteric fever or dysentery by. himself, he would look on the matter in apdifferent light to that which he does at present.

There are many links in the chain of disease prevention, and the weakness of any one of these links will lead to failure.

No matter how perfect the organisation of a sanitary corps may be, epidemics; of disease will still occur unless precautions are carried out in the very first link of all, i.e., by the individual, and this, to my mind; can only be effected by the instruction of officers and men in the elementary rules of the origin and prevention of disease.

- It is I-think by the combination of these two measures-one, as it were, at the head, and the other at the foot, of Army sanitationthat good results will in the future be effected.

I fear that, in the limited time at my disposal, I have been obliged to touch but briefly on many important points, which were worthy of more lengthy consideration; but I hope that even this short address may have been of some service in bringing to your notice a matter which to my mind-and; I think, to the minds of all Royal Army Medical Corps officers-is of the most vital importance.

Putting aside altogether my personal views and beliefs in the matter, surely there is unlimited clear and indisputable evidence to show how enormously the success of our Army on active service is dependent on its freedom from disease.

When we remember that these diseases are preventible, and that the measures which prove effectual in their prevention are well known, surely it behoves every one of us, in whatever branch of the Service we may be, to unite in recognising the value of these measures, and to spare no effort in seeing that they are carried out.

I hope I carry conviction when I state positively that Army sanitation is no idle fad, no theoretical idea; it is based on proved and indisputable facts, the elements of which everyone in the Army should be thoroughly acquainted with, and it is a subject which will most assuredly force itself on our notice even more emphatically in the future than it has done in the past.

List of works consulted:-

Theory and Practice of Military Hygiene (Munson).

Prevention of Disease in Armies in the Field (Major Caldwell).

On the róle of Insects, Arachnids, and Myriapods as Carriers in the Spread of Bacterial and Parasitic Diseases of Man and Animals (Dr. Nuttall).

A Civilian War Hospital (Drs. Tooth and Calverley).

Tropical Diseases (Munson).

Flies as Spreaders of Sickness in Camps (Dr. M. A. Veeder). 
Report of the Commission on Dysentery and Enteric Fever in South Africa.

Journal of the Royal. Army Medical Corps:-

Volume 1, p. 277.

$\Rightarrow \quad 2$, pp. 651, 721.
$\Rightarrow \quad 3$ pp. 512, 649.
$\Rightarrow \quad 4$, pp. 100, 174, 303, 413, 587, 809.
5, pp. 54, 196, 351.

Journal of Tropical Medicine, 1903.

The Practitioner, January, 1904, September 27th, 1902.

British Medical Journal, December 10th, 1904, February 4th, 1905.

Lieut.-Colonel A. M. Davies, R.A.M.C. :-I have no words of criticism at all to make on Major Goodwin's excellent paper, because I thoroughly agreo with every word of it. I feel that it is extremely comprehensive, and that it is oxceedingly sound. I would like, however, with your permission, Sir, to make one or two observations on two points, more in amplification of what he has said and by way of personal illustration. First of all, with regard to tho co-operation of combatant officers, I think that that is one of the most important points of progress that wo can desiro-to get the hearty co-operation of combatant officers, becauso without it I am afraid wo shall not advance very far. If we have that hearty co-operation, then wo can do everything. Tho army medical officer by himself has not at present sufficient power and sufficient means of taking action to carry out the measures that ho knows to be absolutely necessary, but if we had the co-operation of the combatant officers, these necessary measures would be carried out. In order to get that hearty co-operation, the combatant officer must understand what is requirei, and therefore he must be instructed. It is absolutely necessary that he should know the reason for the things which hare to bo done, as Major Goodwin has already stated. In ono of the Bluo Books with regard to the South African War, which give such very shocking and horrible reading to anybody who is interested in Army sanitation, it is related that somerwhere near Pretoria a civilian medical officer saw a party of men coming to draw water in order to fill their water-bottles. There was a dirty littlo. stream running through the field, and the party of men, with their commanding officer, came up and filled thejr bottles at this stream. At a very short distanco further on, a pipo supply of water had been laid on at very great expense, the water being of good quality. The cirilian doctor went to the officer commanding tho party and said : "Do not you see that your men aro drawing this filthy, poisonous water; why do you let them draw it?" and the officer replied : "What can you do? The men will do it; you cannot stop them." You can imagine the observations that should be made to that officer as rell as I can. When $I$ was in India making enquiries into enteric fever at different stations-I am speaking about the dry earth system of excreta disposal, of which sou all know-I came to a certain place. I think I have a fairly largo acquaintance with the dry earth system in latrines, but' nowhere, as far as my experience goes, have $I$ found it well carried out except in one regiment-only once in all the places I bavo boen to. In the particular station to which I am referring it was very badly carried out indeed. I was going round the lines with the commanding officer, and haring been to one latrine after another with him, and found tho most disgusting state of things, I said:" "Sir, your men are not using

voit، $\mathbf{L}$, 
the dry carth; why do not you make them do it?" He said: "What can you do? They will not do it; you cannot make them." Whether in one case the officer says you cannot stop them, or in the other case the officer says you cannot make them; whether it is in one case drinking dirty water when there is clean water ready to drink if they will only take the trouble to get it, or in the other case not using the dry earth, surely that is a matter of discipline, in which there ought to be no difficulty, in a body of men living under authority, as military men are, in getting the orders and regulations carried out. I beliere that if combatant officers were imbued with a knowledge of the reasons of these things-that it is not a mere fad, but that there is a sound scientific basis for all the regulations which are put forward-I believe they would see them carried out. At present they are not imbued with that idea, and they do not fully understand it, and I am afraid they do not, as a rule, seo that the regulations aro carried out. What is required is for the commanding officer to take tho matter seriously. I am convinced there is a rery widespread, although not universal, interest in sanitation amongst combatant officers. I am happy to say that I have cone across many instances where combatant officers are as keen as anybody could possibly be. In one instance of the faulty application of the dry earth system I wont to the general and asked him if he would be so condescending as to, come to a latrine with me, which he did: He was horrified; ho was disgusted; he was enraged, and rery angry with exerybody, including myself. He did not let the sun go down on his wrath; he published a general order that evening, and ordered that every latrino was to bo inspected $b \dot{y}$ a combatant officer every day till further orders. I need hardly say that the latrines in that station-I will not mention it by name (it was in Asia)-were in a very much better condition afterwards than they were before. Then it is obvious that wo must preparo in peaco for what we shall have to go through in war, and that is really what Major Goodwin has alluded to. With regard to tho question of water supply in peaco time, the soldier in barracks, and, generally speaking, when camping out, is provided with a very pure supply of water, and all he has to do is to take it out of the taps. In timo of war, howerer, quite the reverse is the case. All the preparations have to he made by himself for supplying himself with water. There is no water laid on for him. These conditions ought to be rehearsed and prepared for in timo of peace. Another point which $I$ think is most important is the question of water discipline. The men ought not to bo allowed to take water when they want it. Whenever they feel thirsty they aught not to drink. On the march in India the men empty their water-bottles very early in the morning, and go thirsty for many hours together; therefore they will be apt to drink any kind of dirty water they come in contact with. Water discipline ought to be taught, so that the men should only drink in smaller quantities at stated intervals. That, I hold, can oniy be brought about by the personal example of their officers, and officers who are present, will understand the extreme importance of that point. Then with regard to the question of the disposal of excreta in barracks in peace time, as the lecturer has said, the soldiers have nothing whaterer to do with it. It is entirely automatic; he has himself nothing to do, but in time of war he has to do everything for himself. He has to dig trenches, or put on dry earth, or whaterer it is. The other day I came across an instance where a regiment, which had been in .barracks where water latrines were erected, and whero they had nothing whatever to do, were moved to another barracks where the dry. earth system was in 
force, where a man ought to add the dry earth himself erery time he uses the latrine. These mon, as I say, had been accustomed to doing nothing, and when they went from one barracks to another they continued doing nothing. As you can imagine, the condition of the latrines was rery soon appalling, and I have no doubt whaterer that a considerable outbreak of enteric ferer that occurred resulted from this neglect. It was very difficult indeed to get the men to carry it out, and the commanding officer had to take strong measures, which he did by having a patrol to go round and make prisoners of anybody they could catch not putting on the dry earth. That is a case in which it ought to have been somebody's business to gire the men a warning beforehand on that particular point. Then the only other point I wish to refer to, is that preparation in time of peace can only effectually be carried out by having manceuvres un a practical scale, whero the men will have to do the things which we know they will have to do for themselves in time of war. By this means, and by this neans only, can they be properly trained how to deal with active service conditions.

The Revi: W. B. Dowdixg, Ghaplain to the Forces, London :-I will not detain you by making any lengthened remarls, because it is not in my province to do so, when there aro so many ablo officers present who aro capable of expressing valuable opinions on the subject. I have risen simply for the purpose of asking whether the lecturer, or anybody else, will do this for us: Let us know what a man can best do in the matter of eating and drinking in order to aroid theso attacks of disease to which reference has been made. I quite acknowledge that the sanitary rules laid down by the lecturer are very wiso; but $I$ equally understand the statement of those who say that you cannot make a man do certain things, and you cannot prevent him doing certain others. I think all of us have come across that sort of man. I therefore think it would be very helpful if the lecturer would state, for the information of the men and officers alike, how a man'can best defend himself against attacks of diseaso-in viow of its inevitable occasion by tho exigencies of warhow he can best keep himself in health on active service. For instance, what should he eat? Cannot tho lecturer suggest to the Commissariat Department something better than the crerlasting bully beef and biscuits? And cannot the medical authorities suggest some special sorts of food for different climates? And when during the day a man should drink, and what ho should drink? - I also think it would be desirable if the question of the use of alcololic stimulants on active service were gone into. That is a question which, to my mind, people seem to shirk, partly becauso it is a question on which there are differences of opinion, and partly becauso it is not $\dot{a}$ particularly popular ono-on one side at any rate. While I have been on the Council of Army Temperance work-which means for the last twenty years-I have made it my special object to do all I can to promote temperance; but I cannot help feeling some misgivings with reference to tho relation of total abstinence to enteric fever. I speak under correction, but $I$ believe there is no doubt there was an intention to show after the late war that those who were total abstainers were more free from enteric than those who wero not; but that the enquiry resulted in the opposite conclusion, and nothing more was heard of it. hat the real truth is $I$ am not in a position to say. I haro known instances rather bearing out that statement. In a foreign station where I was quartered (it was not an unhealthy station), in one sear three men died of enteric, and because all those three men happened 
to be total abstainers the other men took stringent measuras to einsuro that they should not die of total abstinence. It was a curious fact that the three leadicg total abstainers were the only three men who died from enteric. Such a question as this might reasonably be asked: Would a regular supply of rum during thoso terrible reeks in Bloemfontein, during which I was one of the on-lookers, and helpless, in a way, have prevented that awful epidemic? I hare expressed my own opinions on this subject in private discussion, but $I$ would not like to mention them before so learned an assembly as this. Then I think it would also be of great interest if the lecturer could tell us whether some simple remedy could not be recommended for the troops to carry about in their pockets? When I was a small boy it was an old-fashioned remedy to carry about a piece of rhubarb root to chew occasionally when you did not feel up to tho mark. It nerer got any the rowse for wear in the pocket. Could not a simple remiedy of that sort be issued to all the troops, to bo used on the first signs of being "out of sorts," and thus aroid more serious illness?

Major H. P. G. Elkixgtox, R.A.M.C. :-I 'should like ta say a few words about tho question of sterilisers, because Major Goodwin mentioned in the courso of his' paper the Forbes-Waterhouso apparatus. During the manouvres last year we had two patterns of sterilisers on trial during the wholo period, one made by the Lawrence Company and one by Dr. Mallock. Wo found that in actual work on the march they wero too cumbersome to use for overyday work, but were perfectly suitablo when we got into camp. The chief drawback was that they only delivered thirty gallons an hour, and it thereforo took four hours to fill the water cart. That puts sterilisers out of court altogether in their present form, as far as their use on the actual line of march is concerned. In standing camps no doubt they would bo very. useful. I heard a few days ago from the Iawrence Company that, from their experience at the mancurres, they had modified their original steriliser, and had considerably reduced its size. The ono they sent. us was about 4 feet high, and when we wanted to deliver the water into the cart, it made a hugo mountain, as we had to stand it on a packing case. Another drawback to the uso of the steriliser was the absolute necessity of haring a mechanic trained by the company who understood every detail in connection with tho working of the machine. The lamps in both the Mallock and the Lawrence apparatus worked perfectly well, and gave no trouble, even if the wind was blowing hard; but there was always a difficulty in dealing with muddy water. Wo had to clarify the water before putting it into the steriliser. One of the main reasons for that is, that,if not done, you will clog up the pipes before rery long, and the whole apparatus would be put out of working order. With regard to the question of filters, Messrs. Slack \& Brownlow have a very good field service filter, but their greatest improvement is the field servico water cart. Wo had two patterns on the manœurres, one with the filtering apparatus fised behind the cart. This was the first one shown to the Army authorities; but wo found after the first day's hard rork across the Long Valley it leaked from the joints, and the rater cart was useless. The second pattern, with the filter sunk in the body of the cart, gave most satisfactory results. I handed it orer.to an officer commanding a double company, and, having explained the working of the apparatus to him and the four men that he told off to look after the cart, it was found that they looked after it thoroughly, and took the greatest interest in the working of tho machine. The cart ras filled by tho men by a hose pipe fitted to the machine 
through its own pumps, and also in the ordinary way by tho Royal Engineers' hose. Wo used all hinds of water; we did not mind what we used, as wo took it for granted that, as tho machine was sent down t) us for trial on the march, Slack \& Brownlow's apparatus was capable of giving us sterilised vater. The water was used by the officers' mess, in addition to the company's mess, and we never had any com. plaint whatever. I examined the candles regularly to seo that eversthing was going on all right, and also the asbestos corering; and as $I$ found, in spite of the dirty water we used on the line of march, that tho inner layers of the asbestos did not become eren soiled, I did not sterilise the asbestos or the candles during the nine days we wero working the apparatus.' To show you how well the cart worked, I need only say that the water obtained from the filters was seven gallons in one and a half minutes when we commenced to use it, and at the end of nine days' consecutive work with all sorts of water, it was only reduced to soren gallons in two minutes. Certain modifications aro to bo made in the apparatus, and $I$ was sent only two days ago a photograph of the improvements which were found necessary. : With regard to the subject of special men being told off for the carts, I think that would bo absolutely unnecessary, and would bo multiplying tho number of what you might call Staffemplosed men. There rould be no difficulty whaterer in training any man in the reginent to look after the cart, to sterilise the candles and clean the asbestos, provided you induce the regimental officer in chargo of the company to take an interest in the subject of giving his men good water. I do not think you will have any difficulty in doing that if you go the right way about it; we had none on tho manouvres with the different companies to which the special appliances were told off. They all took the greatest interest in the matter, and gavo, us the utmost support. The men who should be trained for the purpose are undoubtedly the coolss, because on arrival in camp the water-cart is almost invariably placed adjacent to tho kitchen, and with a kettle attached to tho watercart there would bo no difficulty in the cook sterilising the candles and cleaning the asbestos. With regard to the question of water discipline, it was proved on tho manceurres that that can be obtained if sou go to the officers and ask them to carry it out. I had the fullest support from the general officer commanding and the other regimental officers, and in those cases in which wo tried. it we had no difficulty whatever. In the morning all the water bottles were filled with pure water, the cart started off full, and it was filled up again at intervals as required when the men had a halt; but the men were not allowed to get any other water except that which was drawn from the cart itself. That proves, I think, that if the medical officer will get the combatant officers, and more especially the non-commissioned officers, to interest themselves in this subject they will back sou up and do everything that you require. With regard to the question Major Goodwin raised of digging latrines in peace timo when the men have a halt for half an hour or longer, it certainly seems the right thing to do. I suggested it at Aldershot, because we found that on large field days the men fall out and practically foul the ground all round, and on going over the ground the following day you could see perfectly well whero the regiments had halted. We raised this question and tried to see if it was feasible to do anything, but found it would be impracticable, from a regimental point of view, to dig trenches. The best we could arrange for was that parties of men on these largo field days should bo told off, when a halt was called, and by means of a flag or somothing of that sort should indicate where the men could fall out 
for Nature's purposes, so as to limit, as far as possible, the fouling of the ground. Looking at it from a practical point of view, on marches and ficld days that is as much as we can hope for.

Colonel E. A. Althus, C.B., C.M.G.:-T haro very little to say on this interesting paper. I simply rise as a combatant officer, in order to express my entiro sympathy with the subject on which tho-lecturer has touched and has so ably placed beforo us this afternoon. I think when the question of sterilising water on active service was first brought forward some few years ago after the South African War, there was a certain fear on the part of some of us who had more or less to do with staff duties that the limitations which active service necessarily places on the preservation of life had been a little bit over-looked. The conditions of war are so entirely in contrast with those of peace on this point that we cannot expect to carry out tho same system. In peace, the very first duty of the community is to preserve Fifo; in war, the whole object of operations is to take lifo - to take the life of the enemies' soldiers. But in doing so, -in beating down tho enemy by destroying his soldiers, we have to uso up - more or less the lives of our own soldiers. Every general who fails to realise this truth, who shirks from sacrificing the lives of his soldiers when necessity arises, is an incompetent commander. On tho other hand, every general who fails to economise the lives of his soldiers whenever the necessities of the war permit, is equally eriminal and equally culpable. Then, in $\mathrm{war}$, we seem to get a balance of two conditions; they are both opposite to each other; and yet they have to be borne in mind by the responsible military authorities. There are occasions on which tho lives of one's own men become a matter of indifference compared to that of defeating the enemy. There are other occasions on which thero is no immediate opportunity of destroying the enemy, and, therefore, it becomes of paramount importance to preserve the lives of the men whom you will use at some future date for your military purposes. I only troubled you with these points because they seemed to me to bring out more or less the general principles which have a certain practical knowledge bearing on what wo can do on serrice, and what wo cannot do on serrice; and it is haring regard to that practical bearing that $I$ would congratulate the lecturer very much on the moderation and restraint with which ho has approached the subject. I think throughout the lecture, and throughout the remarks which other speakers have addressed to the meeting, the military necessities of service have been constantly and continually borne in mind. On service, I take it, the most difficult problem is that of transport. It was the question of tho extra transport, the extra costs, the extra rehicles, and the increased number of animals which would be entailed which frightened many of us when this question of sterilisation was first mooted, and personally, it was a great satisfaction to mo to hear from the last speaker that a cart has been lately tried down at Aldershot, which, I understand, will suffice for the supply of water -for 500 men. If that is so; it facilitates the solution of the problem to an enormous degree, because it means that for an Army Corps some serenty extra vehicles at the outside would suffice to preserre the whole Army Corps from this great danger of enteric ferer. Subject to those limitations, I am quite certain there is no combatant officer in the -whole Army who will not do the utmost in his power to preservo tho lives of those for whom he is responsible. That it should be possible, for instance, for those things to haro occurred, which have been mentioned this afternoon, such as an officer being indifferent as to whether his men 
drew water from a dirty or a clean - source, or indifferent to the most simple forms of sanitation, is a lamentable thing; but $I$ cannot but hope that, if not at the present moment, at any rate in the.very near future, these things will not happen in tho British Army.

Colonel G. H. SiM, C.B., R.E., Commanding Depôt, Chatham :The question of the individual sanitation of erery man in the Army or in a force is a point of equal importance with the question of whether the authoritios can provide him with good water. On active service wo have to consider many cases where very small parties of men are detached from their main bodies, and very likely remain for some time in ono place. It is impossible that water-carts which aro suitablo for a battalion could be of any service to small outposts of a company that are; say, two miles away on the top of a hill. We must, I think, not only get tho knowledge which the lecturer saws is necessary for every non-commissioned officer and man, but we must get - the practice. Tho only way in which we can get that practice is at manœurres; and not only at mancuvres but on every winter march that a battalion takes for exercise, sanitary rules should be observed. For instance, when there is a fivo minutes' halt, why should men be allowed to foul their neighbours' ground? Every man has a spade in the form of his bajonet. The great thing to do is to prevent the pollution of the soil with a view to preventing the water supply being contaminated; and to prevent the pollution of food by flies. Erery man should be made to understand in peace time whero he can go safely for Nature's uses without the fear of polluting the water supply of the. country. Why should not erery man dig his own littlo hole in the ground and cover it up? That would prevent flies getting at the excreta, and if that is done the risk of pollution of food and water is minimised. - I think it is a personal matter altogether. We read about latrine trenches in the regulations; but $I$ have nerer seen the idea propounded in them that when a man has used the trench, he should cover up the oxcreta himself. I have seen that plan carried into effect in South Africa with great effect, when it was insisted that every man who went oren to urinate should cover up his urine with a little dry earth. There was nothing to atiract flies, and consequently there were fer flies. In - many block-houses that arrangement was carried out, with the result that thero was almost an absence of flies, and the men wore perfectly healthy. It is personal sanitation which should be practised by overy single man in tho $\Delta$ rms, although prepared and supervised arrangements aro equally necessary for camps and largo bodies of troops. 'If at manouvres the officers had to go out and find water for their men, there would be very little chance, after some practice, of their using bad water. They would understand how to get good water somehow or another, or to treat it if not good. Thero is one question I should like to ask the lecturer about the sterilisation of water. He talked about the boiling. I was under the impression that it ras not necessary to boil tho water, but that if the water was brought up to a tèmperature of $190^{\circ}$, and lept at that temperature for a little while, all the bacteria of enteric wero destroyed. That is a rather important point, becauso the lecturer mentioned that if you boil water you mako it unpalatable. If you only bring water up to somothing under boiling temperature, it remains palatable. In standing camps, where thermometers can easily be obtained, it is rery much better that people should Fnow that, and should not make the water unpalatable by excessire boiling. Whero there is no thermometer it is safer to boil 
it, and run the risk of it being unpalatable. With regard to the measures that should bo taken for sterilising water, I cannot help thinking that tho prindiplo which should be adopted is that whenever large bodies are togother and sterilisers and filters are feasible, they should bo used, but that immediately you get small parties away from tho main bodies, thero should bo some means of sterilising the water by chemical action, and that every man should carry somo sterilising stuff in his pocket, so that if the water is doubtful he could put in a small quantity, which would mako that water at any rate safe. If it makes the water a littlo unpalatable, ham not suro that that is not rather a good thing, becauso we have heard a good deal about men drinking an excessire quantity of water, and if the water is not very palatable, perhaps that ovil might bo remedied. I think ono great reason for excessive drinking on servico is the "bully beef." " "Bully beef" is essentially thirst-producing food; there can be no doubt about that, and thore is no doubt that men get into the habit of drinking after a short courso of it. I think something might be incented a little less thirst-producing than "bully beef" in a hot country. There is just one more point I should like to refer to in connection with sanitation, namely, that it would be a good thing if tho King's Regulations or some other regulations. which aro applicable to the whole Army gave a few paragraphs of what a soldier is not to do in the way of sanitation, and that if he is ever found doing one of thoso things he should be liable to punishment just as much as he is if he commits any other military offence. There are no personal sanitary regulations that I know of at all, and the consequence is that every officer has to make laws for himself and do the best he can with his men. If a fow regulations were drawn up, and a man could be actually punished for doing things that he is told not to do, it would be a great assistance to the combatant officers. There is one little point with regard to malaria I should like to mention. I have found that paraffin oil is - of tho greatest efficacy in the prevention of the bites of mosquitos. Mosquito curtains are all very well, but if a mosquito gets inside-and ho often does get inside-they are not much good. Paraffin oil is used, I believe, largely for the prevention of mosquito breeding in ponds. When $I$ was in India I never had a mosquito curtain at all, although I was rery much subject to being bitten by them. By putting just a little paraffin oil orer the exposed parts of the skin I found that the mosquitos would never come near me. I often told officers about it, and $I$ have practised it myself, not only in India, but also in other hot countries and in Italy, where mosquitos abound, and I have always found it extremely efficacious. The mosquito will not bite if you have paraffin oil on tho skin, and for active service that is rather a useful thing to know. On active service I always carry a little bottle of paraffin oil. in my wallet.

Major T. McCurtoci, M.B., R.A.M.C. :-The paper we have listened to is full of points of the greatest interest and importance to ereryono who has the best interests of the soldier on field service at heart. In the past it has been too much the case that sanitary matters have been regarded as chiefly tho concern of tho medical officer, and that little or no responsibility attached to officors of units in regard to the preservation of the liealth of their men. The medical officer's part is, I think, that of educating officers, non-commissioned officers, and men in regard to sanitary principles, and in the practical application of sanitary methods; but if the best results are to bo obtained, the regimental officer must also do his part. He must consider it his duty to pay careful attention himself 
to sanitary details, and he also must use his personal influence in regard to the sanitary training of his men, gaining their ready obedience to the observance of sanitary rules, and impressing upon them that the efficiency of the cdrps in the field is intimately related to the maintenance of a sound state of health of tho men composing it. Disease hampers an army by the loss of numbers, by causing it to lose mobility, by taking up transport which could be moro adrantageously employed; and diseaso adds enormously to the cost of war, as the men lost or disabled have to be regularly replaced. Apart, therefore, from the lumanitarian point of view, the prevention of diseaso is of the utmost importance in.relation to the success of troops in tho field, and tho general who is ablo to maintain sound health confitions in his army is also likely to win most battles. The question of the prevention of disease is consequently of the utmost importanco to every practical soldier. Sanitation, in its broadost sense, may be summed up in one word-cleanliness. All sanitary measures are based on the necessity for systematic removal of refuse matter and excrata. We ain at proventing the accumulation of such matters-conditions which must occur wherever men aro gathered together, and particularly when the aggregation takes placo within limited areas, such as camps on field service. A camping ground to begin with may bo clean, and in such circumstances the health of the men will not suffer from sanitary carclessness until some time after occupation. In the very best looked-after camps some organic pollution of the soil is inevitable, but if sanitary matters are neglected, unhealthy conditions aro rapidly established, and such diseases as dysentery and enteric fever exact their toll. A good sanitary state in a camp depends on the exercise of care by the individuals living in it. The mon should, thorefore, be trained in sanitary methods in time of peace just as they are trained in drill, in shooting, and in field work. $\Lambda$ man becomes a trained soldior, as far as the use of his weapon is concorned, by constant practice and by going over tho same ground again and again until he becomes proficient. In the same way ho will only gain a satisfactory knowledge of sanitary principles by receiving instruction which is repeated again and again, and instruction in field sanitation should form part of his annual field training:

Captain J. Boorn Cuarksos (late 3rd Bn. Royal Fusiliers) :-Confirming the recommendations of Major Goodwin, to the effect that it would be a very useful thing to have a sanitary corps which should havo charge of the sanitary apparatus, I may mention that I was told by the United States Medical Officer, only about three weeks ago, that not very long ago they had to issue an order against the use of the Forbes. Waterhouse apparatus in the latrines, not because it did not work quite satisfactorily-it did when it was properly managed-but owing to the fact that they found the men did not understand it, and therefore it was more of a danger than a safeguard; but after a certain number of men were trained to use it properly, another Army Ordér was issued to the effect that it should bo used. With regard to the question of training officers and men in regard to sanitary matters, I think that, nearly up to the present time, one of the great reasons that we have not been able to get them to take an interest in it has been owing to the fact that wo have not had rery good results to show; but now that we can point out what Major Goodwin has mentioned, that in the South African War we had 41,000 cases of enteric, whereas the Japanese army in their recent campaign only had 193, wo are likely to make more progress. In addition to that, we can point out the results 
in Havannall, where, under the orders of General Leonard Wood-himself at one time the medical officer to Major $\longrightarrow$, in charge of the United States Medical Department-yellow fover has been stamped out. Yellow ferer was tackled on the lines indicated by the Commission presided over by Major Read, i.e., tho mosquito being exterminated, with the result that a couple of years ago there was not a case of yellow fever in Havannah, for tho first time in a hundred and fifty sears. What would happen if an army that was in the sanitary condition of our army had met a Japanese army in their sanitary condition? . There could be no doubt about the result. Although military reorganisation has not gone as far as wo should like to sce it go, it has progressed considerably, especially pince the days of the pocket-book observation that a doctor's advice was rery good-when it was asked for.

Major T. H. A. C. Goopwis, D.S.O., R.A.M.C., in reply, said :With regard to Colonel Davies' remarks, I hare nothing to say, because he was good enough to agree with me in everything. As to Mr. Dowding's suggestions respecting tho general health of tho mon; I do not think that any instructions as to tho food men should eat, or regarding their clothing, etc., which I presume are the measures referred to, will be of any avail unless the details as to sanitation are understood and carried out by them. To my mind, that is tho most important point of all. There is no reason why "bully beef" or any other food, if uncontaminated, should causo severe diseases; it may produce diarrhoea or dyspepsia, but it cannot cause enteric fever. Enteric fever can only be contracted through defects in sanitation. With regard to tho question of alcohol, I have mentioned it in my paper, but I did not refer to it when giving my lecturo. I do not know what $\mathrm{Mr}$. Dowding's viers are on the subject, but I hare put mine in the paper. I am strongly against the use of alcohol, unless under exceptional circumstances. I think the habitual 'use of alcohol is a very great mistake. Cortainly it is useful at times; for instance, after long marches when the men aro fatigued and exhausted, but I think that as a rule it is productive of more harm than good. I think the habitual issue of alcohol in cold weather is certainly harmful; it induces a feeling of warmth because the surface of the body is flushed. The person feels warmer, but that simply means that so mucli reserve heat is lost by evaporation, and the body is then less fit to combat the cold. I think those are the principal points regarding alcohol which I mentioned in the paper. Is regards simple remedies which the soldier can carry, I do not think that such a measure would be very practicable. My own experience of the gentleman cadet at Woolwich is that one has to be very careful as to what simple remedies one gives him. If a doctor gives him something for external use, say for application to his knee, unless the cadet is very carefully instructed, ho will probably try its effect on somebody else's throat, or internally on himself, and I think it is very much the same with the soldier. He does not understand the possible danger of the drugs with which he is dealing. Even if such a measure were practicable, I am not acquainted with any simple remedy which will either prevent or cure enteric ferer or dysentery. With regard to Major Elkington's remarks, I am very glad indeed to hear that my idea was correct as to the new pattern water-cart having been successful. I heard that it promised very well, but I did not know that the results had been so very satisfactory as appears to be the case. Major Elkington also said that specially trained men wero not necessary to ensuro the efficient working of the cart, but he mentioned afterwards 
that one man was trained in the subject. That, I think, is a proof of my contention that one man, at all events, should be skilled in the matter, and that the apparatus should not be handed over to the ordinary man, who was not trained as to its mechanism. Colonel Altham spoke of the rery great difficulty of transport. I fully appreciate and understand the force of his remarks, and it was principally for that very reason that $I$ thought that boiling water would in future be the more effective method at the base and on the lines of communication. At the front $I$ think filtration is the better mothod, becauso it can be more easily carried out, while involving a much smaller amount of transport. Colonel Sim spoke of boiling the water and as to the alternative method of raising it to a temperature of only $190^{\circ}$ instead of to the actual boiling - point. He asked if that was effectual. . It is so, but I did not mention it because I thought it rather complicated matters. Such a method is all very well at the base and where ingtallations can bo erected and thermometers used, but $I$ think as a general rule that the efficacy of sterilisation by heat is open to doubt unless tho water is boiled. If it is boiled for a minute', or even two minutes, the water does not lose all its dissolved gases. With regard to the question of purification by chemicals, owing to pressure of time I omitted to touch on this point, although $I$. have mentioned it in the paper. There are various means which can be adopted for the purification of water by chemicals. I do not think that, as a rule; they are very practicable on active service. There are many difficulties in the 'way; but, at the same time, I do think that there is scope, and ample scope, for their employment in the ease of small bodies of men, such as picquets and scouting parties. Tho best method .I havo seen is that of Vaillard, in which the water is purified by the action of free iodine, which is subsequently neutralised: The materials for carrying out the process are very easily carried on the person, and I think the method would bo found useful for small bodies of men at the front. Mention was made of the employment of paraffin oil as a specific against the bites of mosquitos. I tried paraffin oil myself in India. It is all very well when you can apply it frequently to the exposed parts, such as the hands and face. It then certainly does keep off the mosquitos, but the oil has to be constantly renewed; and when you remember the fact that the Anopheles mosquito feeds throughout the night, I think sou will seo that paraffin oil. is not very effectual. When one goes to sleep the paraffin soon evaporates, and the Anopheles mosquitos will then bite as freely as before. I found that in India in the easo of tho ordinary mosquito (the Culix), paraffin oil would keep them off for an hour, and then they got as bad as ever. I was rery glad to hear ono remark, namely, that the non-commissioned officers wero so interested in the caro of sterilisers and other apparatus. I think that is most important and encouraging, becauso tho non-commissioned officer has a very valuable influence. He gets hold of the men under him and sets an example, and can effect very good results indeed at rery littlo cost to himself or anyone else.

The Chainuan (Surgeon-General A. Keogh, C.B.) :-I think we have had an exceedingly interesting discussion on this paper, and that $I$ havo been left rery little to say by way of summing up what has been mentioned. It is a source of somo regret, to me at all erents, to find that the majority of those who aro here are medical officers, and that the combatant branch of the Army is not rery well represented; but one is consoled by the reflection that this paper will be read throughout the 
Service, and we hope it will have the effect which it undoubtedly deserves. I think the paper is an exceedingly. valuable one. Major Goodrin has been yery moderate in the statements that lie has made. He has touched upon most important matters which should occupy the attention of tho combatant officer. Of course, as he said, he does not expect the combatant officer to be an expert in sanitation; he only requires him to appreciate the fact that sanitation has now, and has had for the last twenty years, a scientific basis. Perhaps I may be allowed to express my own opinion on ono or two points that were mentioned. Personally, in the strict sense of the term, I do not believo in a sanitary corps, because it would be a mistake to reliere units wholly of their sanitary responsibility, and if wo had a branch of the Army dealing with nothing but executive sayitation, in all probability sanitation would very soon pass out of tho domain of the battalion. I hold very strongly that a battalion must safeguard itself. I also thold that it is possiblo within the personnel of a battalion to adopt all the measures-provided the officers and men aro educated as to the necessity for these measures-which are necessary for the sanitary salvation of the battalion. But if we come to consider the conditions which prevail at the base and on the lines of communication, then $I$ do not think the principle that the sanitary salvation of a battalion depends upon itself will help us in the least, because, as a matter of fact, on lines of communication and at the base we bave no permanent battalions. Sanitation must there be preserved by a permanent personnel. If Major Goodwin means by a sanitary corps bodies of men of the Royal Army Medical Corps, who are trained, educated, and uted for nothing else (because I always hold sanitation is a subject which requires constant and unremitting attention), if these men are used for nothing else on lines of communication and base, then one can understand what he means by a sanitary corps. I hold that if wo were ablo to translate into practice these viers the Army rould enormously benefit. Of course, Colonel sltham was quite. right. There is no doubt whatever about it that, after all, soldiers go to war to fight and win battles, and in a humanitarian senso they do not care in tho least about sick and wounded and all that sort. of thing; why should they? That is our business; but wo hold that this is not a humanitarian question at all. 'This is a case of the fighting and the winning' of battles. For the moment, let us say, wo do not care about sick and wounded; we still have a very important function in war, and that is the preservation of the army from disease. If, as Colonel Altham says, we are going to inundate an army with more transport, more personnel, and so on, it becomes a question whether the game is really worth the candle. Personally, I think that is a matter which the combatant officer must decide. We have the greatest sympathy with the commander in the field. He is suddenly called upon to receive, in addition to the cnormous establishment given to him for the care of the sick and wounded, another establishment for the prevention of disease. In time it is not difficult to imagine that the transport for the prevention of disease and for the cure of the sick and wounded would almost equal the army for fighting purposes. No, I hold that if it be true that sanitary science can prevent disense in war, the combatant officer is entitled to say then: "If these measures are going to be so successful as you tell us they will be, you should reduce the numbers of your hospitals, tho large personnel which you threw into the field, and show us that practical results in military operations aro likely to follow these sanitary proceedings." I think he is perfectly right there. When you como to consider that if wo go to war wo 
should have to make arrangements for 10 per cent. of the force finding itself in hospital in the first few months of the campaign; that menns with an army of 140,000 men, that you require a medical corps 10,000 strong. I think it ought to bo possible, if there is anything in the sanitary question, to reduce the 10,000 people that wo send out to look after the sick and wounded (which, after all, is of no interest to the combatant officer-I speak from the point of view of the combatant officer, of course), and that undoubtedly tho demand to roduce that large establishment is rery well founded. That, I take it, was tho meaning of Colonel Altham's remark, and it is a very sound and sensible remark, too. I cannot criticise at tho present time the many other interesting questions that havo been raised in connection with the matter. In stating my own riew as to the formation of a sanitary corps, I feel there that, in the main, I am in unison entirely with Major Goodwin. The paper, as I have said, is of very great value, and one hopes that through the medium of this great Institution it will find its way throughout tho Service, that it will prove to be a means of educating tho Army in this great and important question, and that perhaps it will enablo us medical officers to. push forward the great cause that we have at heart. Before I close I should like to ask jou to pass a harty rote of thanks to Major Goodwin for his most interesting and excellent paper. 